DOI: 10.32089/WBH.PHW.2021.1(275).0009

orcid.org/0000-0003-4077-8709

\title{
Sadyści zamiast owładniętych ideologią? Odpowiedź na polemikę Oscara Szerkusa „Ruch oporu? Terroryści!”
}

Oscar Szerkus, „«Ruch oporu? Terroryści!». Odpowiedź na recenzję Temida Polskiego Państwa Podziemnego pod lupą niemieckiego badacza autorstwa Leszka Kani," Przeglad Historyczno-Wojskowy (PHW) 21, nr 4 (274) (2020): 200-211.

Ostatnio w „Przeglądzie Historyczno-Wojskowym” ukazała się odpowiedź Oscara Szerkusa ${ }^{1}$ na recenzję jego publikacji. ${ }^{2}$ Leszek Kania, co zauważył również Autor odpowiedzi, pozytywnie odniósł się do publikacji Szerkusa i w syntetyczny sposób przedstawił ją jako ważny przewodnik po polskim podziemiu dla niemieckiego czytelnika, a także wyważoną w sądach i zawierającą kompleksowe spojrzenie na polski wysiłek zbrojny. Popierając stanowisko Autora odpowiedzi o cennym wpływie recenzji na rozwój dyskusji naukowej, chciałbym się jedynie odnieść do przywołanej w niej argumentacji na temat osób wchodzących w skład aparatu policyjno-administracyjnego - czy też szerzej obywateli - III Rzeszy przebywających na zajętym terenie państwa polskiego, w tym Generalnego Gubernatorstwa (GG), a także przyjętej przez Niego terminologii.

Autor zauważył, że intencją jego publikacji było wykazanie, że sądy Polskiego Państwa Podziemnego były „prawdziwymi sądami, które wymierzały sprawiedliwość w imieniu Rzeczypospolitej i były do tych czynności w pełni uprawnione" (s. 202). Dalej zaś argumentuje powyższą kwestię brakiem uznania w tym zakresie trwałej praktyki czy paremii rzymskiej, odnoszącej się do

\footnotetext{
1 Oscar Szerkus, „«Ruch oporu? Terroryści!». Odpowiedź na recenzję Temida Polskiego Państwa Podziemnego pod lupą niemieckiego badacza autorstwa Leszka Kani," Przegląd Historyczno-Wojskowy (PHW) 21, nr 4 (274) (2020): 200-211.

2 Leszek Kania, „Temida Polskiego Państwa Podziemnego pod lupą niemieckiego badacza," PHW 20, nr 3 (269) (2019): 192-202.
} 
obrony koniecznej (s. 202-203). Autor wskazał, że „napaść na Polskę nie skutkowała anihilacją polskiej państwowości, tylko spowodowała tymczasowe jej zawieszenie" (s. 204). Wbrew opinii Autora nie nastąpiło zawieszenie polskiej państwowości, bowiem pomimo nacisku innych państw, władze Rzeczypospolitej nie zrzekły się suwerennych prerogatyw państwowych. Na mocy art. 24 ust. 1 Konstytucji Rzeczypospolitej ${ }^{3}$ Prezydent Józef Mościcki z dniem 25 września 1939 r. wyznaczył swojego następcę. ${ }^{4}$ Nowy prezydent Rzeczypospolitej, którym w konsekwencji z dniem 30 września 1939 r. ${ }^{5}$ został Władysław Raczkiewicz, mówił: „Zarówno ja, Prezydent Rzeczypospolitej, jak i rząd korzystający przejściowo z serdecznej gościny sprzymierzonej Francji uważamy się tedy za mandatariuszy kraju na okres wojny [...] W ramach Konstytucji kwietniowej postanowiłem te jej przepisy, które upoważniają mnie do samodzielnego działania wykonywać w ścisłym porozumieniu z Prezesem Rady Ministrów [...] Ślubujemy, że uczynimy wszystko, aby tę wojnę ramię przy ramieniu z sprzymierzonymi z nami [...] narodami Francji i Anglii doprowadzić do zwycięskiego końca [...]. W tym celu tworzymy we Francji i w Wielkiej Brytanii armię". Nadto w 1939 r. nastąpiło zaprzysiężenie Rządu Polskiego na Obczyźnie ${ }^{7}$ oraz powołanie Naczelnego Wodza i Generalnego Inspektora Sił Zbrojnych. ${ }^{8}$ Rząd Polski został uznany przez państwa sprzymierzone, ${ }^{9}$ a częścią jego sił zbrojnych były Siły Zbrojne w Kraju, zaś Delegatura Rządu na Kraj spełniała funkcje administracji rządowej. Nadto należy wskazać, że działanie państwowości polskiej potwierdzało wydawanie dekretów publikowanych w jawnym Dzienniku Ustaw i Monitorze Polskim, np. wydano dekret o działaniu przez obywateli III Rzeszy lub państw sprzymierzonych na szkodę obywateli polskich, co zostało uregulowane dekretem o odpowiedzialności karnej za zbrodnie wojenne. ${ }^{10} \mathrm{Te}$ uwagi Autora, wobec przytaczania w jego publikacji treści podstaw prawnych

\footnotetext{
Ustawa konstytucyjna z 23 IV 1935 r. (Dziennik Ustaw /dalej: Dz. U./ RP 1935, nr 30, poz. 227).

4 Zarządzenie Prezydenta RP z 17 IX 1939 r. o wyznaczeniu następcy Prezydenta Rzeczypospolitej (Monitor Polski /dalej: M. P./ 1939, nr 213, poz. 2).

5 Protokół zaprzysiężenia Prezydenta RP z 30 IX 1939 r. (M. P. 1939, nr 218/219, poz. 1).

6 Przemówienie Prezydenta RP z 30 XI 1939 r. (M. P. 1939, nr 271/276, poz. 1).

7 Protokół zaprzysiężenia Rządu RP z 30 IX 1939 r.

8 Zarządzenie Prezydenta RP z 7 XI 1939 r. o mianowaniu gen. Władysława Sikorskiego Naczelnym Wodzem i Generalnym Inspektorem Sił Zbrojnych (M. P. 1939, nr 245/251, poz. 1); Dekret Prezydenta RP o organizacji naczelnych władz wojskowych z 27 V 1942 r., (Dz. U. RP 1942, nr 5, poz. 9).

9 Przykładowo można wskazać list króla Jerzego VI do Prezydenta RP Raczkiewicza z 13 X 1939 r., zob. (M. P. 1939, nr 245/251, poz. 1).

10 Dekret Prezydenta RP z 30 III 1943 r. o odpowiedzialności karnej za zbrodnie wojenne (Dz. U. RP 1943 r., nr 3, poz. 6).
} 
działania sądownictwa, tj. kodeksu Sądów Kapturowych Związku Walki Zbrojnej, statutu Wojskowych Sądów Specjalnych Armii Krajowej i statutu Cywilnych Sądów Specjalnych, ${ }^{11}$ a także wobec argumentacji przytoczonej powyżej zdają się zbędne. Należy jednak mieć na uwadze, że czytelnikiem jego publikacji jest niemiecki odbiorca, niemający dużej wiedzy na temat działalności polskiego sądownictwa na terenach GG.

Kolejną kwestią jest używanie przez Autora nazwy okupacja (s. 202, 204, 207) jako oznaczenie stanu prawnego panującego w tym czasie w Polsce. Jak się wydaje, użycie tego określenia, gdy opisujemy terytorium GG, jest niewłaściwe i ma charakter jedynie potoczny. Zgodnie $\mathrm{z}$ art. 42 IV konwencji haskiej z 18 października 1907 r. dotyczącej praw i zwyczajów wojny lądowej terytorium uważano za okupowane, jeśli faktycznie znajdowało się pod władzą armii nieprzyjacielskiej. ${ }^{12}$ Co prawda zarówno $\$ 1$ dekretu Adolfa Hitlera z 12 października 1939 r., jak i proklamacja GG z 26 października 1939 r. podpisana przez Hansa Franka posługiwały się nazwą "Generalny Gubernator dla okupowanych polskich obszarów”, ale dotyczyła ona obszarów zajętych przez wojska niemieckie. ${ }^{13}$ Należy przy tym dodać, że proklamacja Franka, rozplakatowana w języku polskim, posługiwała się nazwą nie „okupowanych obszarów polskich”, lecz „zajętych obszarów polskich”. ${ }^{14}$ Jednak już 31 lipca 1940 r. z nazwy zniknął wyraz „okupowanych” i został zastąpiony określeniem "Generalny Gubernator”. ${ }^{15}$ Było to wynikiem zakończenia działań wojennych w 1939 r. i wydania przez Franka rozporządzeń w dniu 26 października 1939 r. $^{16}$, na mocy których ziemie polskie w GG przeszły pod władzę administracyjną generalnego gubernatora, zaś utrzymanie bezpieczeństwa i porządku pod wyższego dowódcę SS i Policji. To spowodowało zniesienie okupacji wojskowej Polski, a co za tym idzie,

11 Szerkus, Die Sondergerichtsbarkeit des Polnischen Untergrundstaates (Berlin: Duncker \& Humblot, 2019), 424-436.

12 IV Konwencja Haska z 18 X 1907 r. dotycząca praw i zwyczajów wojny lądowej (Dz. U. RP 1927, nr 21, poz. 161).

13 „Dekret Führera i Kanclerza Rzeszy Niemieckiej z dnia 12 X 1939 r. o administracji okupowanych polskich obszarów, A.100," w Prawo Generalnego Gubernatorstwa w układzie rzeczowym z objaśnieniami i szczegółowym skorowidzem, wyd. Albert Weh (Krakau: Institut für deutsche Ostarbeit, 1941), 1; „Proklamacja Generalnego Gubernatora z dnia 26 X 1939 r., A.100," w ibid., 10.

14 „Fotokopia proklamacji Gubernatora Generalnego,” w Kronika okupowanego Krakowa, red. Tadeusz Wroński (Kraków: Wyd. Literackie, 1974), 36.

15 „Dekret z dnia 31 VIII 1940 r. w sprawie nowych uregulowań organizacyjnych w Generalnym Gubernatorstwie, A.102," w Prawo, 8.

16 „Pierwsze rozporządzenie z dnia 26 X 1939 r. o odbudowie administracji okupowanych polskich obszarów A.120,” w ibid., 1-4; „Rozporządzenie z dnia 26 X 1939 r. o bezpieczeństwie i porządku w Generalnym Gubernatorstwie, B.400,” w ibid., 1. 
nie można już w latach 1940-1945 uznawać terenu za okupowany i używać de iure nazwy okupacja. Wywód Autora dotyczący art. 42 IV konwencji haskiej z 1907 r. jest o tyle niepoprawny, że autorzy konwencji opisywali jedynie obszary znajdujące się pod „władzą armii nieprzyjacielskiej”. Również pozostałe postanowienia ww. konwencji, posługujące się terminem okupacji, odnoszą się stricte do władzy wojskowej nieprzyjaciela, np. kontrybucja na rzecz armii na pisemny rozkaz generała (art. 51), rekwizycje dla armii nieprzyjacielskiej (art. 52-53). Formułowane tam również zakazy dla armii i państwa nieprzyjacielskiego są związane - jak wynika z tytułu działu III ww. konwencji i wykładni literalnej tych przepisów - $\mathrm{z}$ „władzą wojenną” (dział III: „O władzy wojennej na terytorium państwa nieprzyjacielskiego”). Konwencja nie przewidywała sytuacji, gdy władza wojskowa nieprzyjaciela zostanie zastąpiona przez ustanowione przez niego władze administracji cywilnej, w tym wypadku powołanie Generalnego Gubernatorstwa, które zlikwidowało władzę armii. Dziwi to tym bardziej, że jak wynika z treści odpowiedzi, tekst IV konwencji haskiej jest Szerkusowi znany.

Autor odpowiedzi w nawiązaniu do stwierdzenia Leszka Kani, że polscy autorzy nie prowadzą pogłębionej analizy legalności wyroków podziemnej Temidy, bowiem jest to dla nich oczywiste, wskazał, że jego zdaniem „na tle aktualnej polityki należy takie analizy prowadzić nie tylko w pracach prawno-historycznych" (s. 205). Powyższe stwierdzenie można skwitować brakiem po stronie polskich historyków i prawników konieczności „wyważania otwartych drzwi". Z drugiej jednak strony należy zauważyć, że uznanie za pewnik legalności działań sądów podziemnych i nieprowadzenie w swoich pracach pogłębionych analiz w tym kierunku nie powoduje - czego Autor zdaje się chyba nie zauważać - że takich analiz nie wykonywano. Przykładowo zrobił to chociażby autor niniejszego opracowania w publikacji, która została zacytowana w pracy Oscara Szerkusa jako jedna z książek, na których się oparł, a zauważył to również recenzent jego publikacji. ${ }^{17}$

W odpowiedzi Autor przywołał fragmenty korespondencji kilku wkraczających do Polski w 1939 r. Niemców. Miały one poprzeć jego tezę o nieprzyjaznym odbiorze Polski przez „przeciętnego okupanta” (s. 206). Na wstępie należy zaznaczyć, iż trudno wymagać, aby ludność napadniętego kraju witała najeźdźcę z kwiatami, zaś przeprowadzone naloty bombowe nie pozostawiły po sobie żadnych zniszczeń. Czyżby przez ten zabieg Autor chciał zbagatelizować znaczenie terenów Polski w planach niemieckich? A jak się to ma do doktryny poszerzania przestrzeni życiowej dla Niemców na Wschodzie? Bo chyba Autor nie stara się udowodnić, że zdobycie Polski

17 Bartłomiej Szyprowski, Sąd Kapturowy przy Komendzie Głównej Związku Walki Zbrojnej $w$ Warszawie (sierpień 1940 r. - listopad 1941 r.). Podziemie w walce ze zdrajcami Rzeczypospolitej (Warszawa: Księgarnia Historyczna, 2016), 49-54. 
nie interesowało kierownictwa III Rzeszy. W ramach polityki przesiedleńczej III Rzeszy wynikającej z Generalplan Ost „zdobyte” na wschodzie tereny miały zostać w przyszłości całkowicie zgermanizowane. Temu służyło uznanie Zamościa za miasto „historycznie niemieckie”. Koncepcję tę zaczęto realizować na Zamojszczyźnie w drugiej połowie 1942 r., gdzie zamierzano stworzyć pierwszy obszar osiedleńczy przeznaczony dla osadników niemieckich. Ofiarą wysiedleń, trwających z przerwami od końca listopada 1942 r. do sierpnia 1943 r., padło ok. 110 tys. Polaków z prawie 300 miejscowości (w tym ok. 30 tys. dzieci). Ponad 11,6 tys. osób zostało zabitych w czasie akcji pacyfikacyjnych. Miejsce wysiedlonych zajęli sprowadzeni Niemcy i Volksdeutsche w liczbie około 13 tys. Zamojszczyzna miała stanowić również bazę wypadową do przyszłej kolonizacji Ukrainy. ${ }^{18}$

$\mathrm{Z}$ drugiej strony należy wskazać, że opis terenu Polski przedstawiany w listach jest przede wszystkim obrazem wynikającym z klęski kraju w 1939 r. Podobne źródła można zacytować również w kontekście upadku III Rzeszy w 1945 r. Dla porównania żołnierz 9 Dywizji Piechoty z 2 Armii Wojska Polskiego opisywał swoje doznania: „Jak się patrzało na Niemców to robiło się niedobrze. Byli tak służalczy i sztucznie mili, że w najgorszym czasie nikt się tak u nas nie zachowywał. Dzieci chodziły niemiłosiernie brudne, kobiety o nich jakby nie dbały, a dziewczęta oddawały się za słodycze i kolorowe wstążki. Nie widziałem takiej nędzy nawet na naszym wschodzie, ale ja Niemców za nasze krzywdy nie żałowałem". ${ }^{19}$ Czy takie relacje przedstawiają rzeczywisty i prawidłowy obraz terytorium i ludzi? - nie sądzę.

Swoistym kuriozum jest pogląd Autora odpowiedzi, w którym twierdzi, że zbrodnicze działania wykonywali tylko „prawdziwi sadyści”, czasem wbrew rozkazom przełożonych, zaś dla znacznej części niemieckich funkcjonariuszy życie oraz praca w GG były częstokroć formą kary za nieodpowiednie sprawowanie $\mathrm{w}$ Rzeszy. Jego zdaniem każdy $\mathrm{z}$ nich wiedział, że prawdziwą karierę można zrobić tylko w Berlinie, Monachium, czy we Francji, nie zaś w nieprzyjaznej Polsce. Pisze przy tym, że „byli to w gruncie rzeczy przyzwoici ludzie", a tylko okoliczności wpływały na ich działania (s. 206-207). Przedstawienie takiego poglądu na temat przedstawicieli Herrenvolku polskiemu czytelnikowi, który chociażby z dostępnej literatury popularnonaukowej oraz wiedzy wyniesionej ze szkoły doskonale zdaje sobie sprawę z charakteru niemieckiej działalności w Polsce w czasie II wojny

\footnotetext{
18 Igor Hałagida, „Ukraińskie straty osobowe w dystrykcie lubelskim (październik 1939 lipiec 1944): wstępna analiza materiału statystycznego," Pamięć i Sprawiedliwość, nr 1 (29) (2017): 368; Jerzy Markiewicz, Nie dali ziemi skąd ich ród: Zamojszczyzna 27 XI 1942 - 31 XII 1943 (Lublin: Wyd. Lubelskie, 1967), 17-19, 24.

19 Archiwum Państwowe w Zielonej Górze, Komisja Historyczna Koła ZBOWiD w Zielonej Górze, 89/554/0/71.12/786, Relacja Antoniego Bielunia złożona do akt Komisji Historycznej Koła ZBOWiD w Zielonej Górze, b.m., 14 VII 1974 r., b.p.
} 
światowej, może spowodować niedowierzanie. Jednak historyk i prawnik $\mathrm{z}$ wykształcenia obcujący z dokumentami i literaturą fachową na ten temat skwituje takie stwierdzenie komentarzem „odsyłam do stosownych źródeł”. Dziwi fakt, że Autor stara się wmówić czytelnikowi, iż działania represyjne na terenie GG mogły sprawiać radość jedynie „prawdziwym sadystom”, którzy działali często „wbrew rozkazom przełożonych”, a w gruncie rzeczy byli to „przyzwoici ludzie”. Tym bardziej że nie poparł tego żadnym źródłem. Niestety nie jest to do końca właściwe. Świadomość o swojej uprzywilejowanej pozycji wobec Polaków, których nazywano podludźmi, była powszechna nie tylko u Niemców pełniących funkcje w aparacie policyjno-administracyjnym, ale również u zwykłych osadników wiejskich, których osadzano na gospodarstwach wyrzucanych obywateli polskich z terenu Pomorza czy Zamojszczyzny. Nadto takie podejście jest co najmniej wątpliwe, bowiem działanie członków niemieckich władz policyjnych (Geheime Staatspolizei, Sicherheitspolizei) nie było wynikiem sadyzmu, lecz świadomymi reakcjami Niemców, wynikającymi z antypolskiej ideologii państwowej i rozkazodawstwa III Rzeszy. Frank w swoim dzienniku pod datą 28 października 1939 r. oświadczył: „W Generalnym Gubernatorstwie mogą być zatrudnieni tylko najbardziej aktywni bojownicy narodowosocjalistyczni. Dlatego prosi on [...] o odkomenderowanie odpowiednich, bojowo nastawionych ludzi”. ${ }^{20} \mathrm{~W}$ zakresie wyżywienia uznawał, że „należy bardzo wyraźnie zaznaczyć różnicę między niemieckim narodem panów a Polakami, zaś w zakresie zatrudnienia musi obowiązywać zasada, że panem kraju jest Niemiec, a Polak musi to akceptować". ${ }^{21}$ Już 27 grudnia 1939 r. 31 Pułk Ordnungspolizei rozstrzelał w Wawrze pod Warszawą 106 mężczyzn, a jednego powiesił w odwecie za zabicie dwóch podoficerów niemieckich. Chociaż sprawcy zabójstwa byli znani policji jako zawodowi przestępcy, nie powstrzymało to Niemców przed zamordowaniem niewinnych Polaków. ${ }^{22}$ Czy "sadystą” była osoba wprowadzająca w grudniu 1939 r. urzędową szykanę dla ludności polskiej w postaci wydzielenia pierwszego pomostu tramwajów nur für Deutsche? Czy można takimi nazwać osoby, które dokonały w okresie od 30 marca 1940 r. do 24 kwietnia 1940 r. masowych aresztowań przedstawicieli polskiej inteligencji? Aresztowania

\footnotetext{
20 Archiwum Instytutu Pamięci Narodowej w Warszawie (dalej: AIPN), Generalny Gubernator w Polsce 1939-1945, GK 95/1, Dziennik Hansa Franka od 25 X 1939 do 20 XII 1939 r. (dalej: GK 95/1), Sprawozdanie ze spotkań Hansa Franka z podwładnymi oraz przedstawicielami wojska i policji niemieckiej, Kraków, 29 X 1939 r., 8-13; Hans Frank, Rok 1939 w dzienniku Hansa Franka, wstęp i oprac. Paweł Kosiński, tłum. Wiktor Grotowicz (Warszawa: Wyd. Instytutu Pamięci Narodowej, 2019), 32.
}

${ }^{21}$ AIPN, GK 95/1, Narada Hansa Franka z wyższymi urzędnikami administracji, Kraków, 30 X 1939 r., 23-31; Wizyta Hansa Franka na konferencji landratów Dystryktu Kraków, Kraków, 8 XI 1939 r., 45-53; Frank, Rok 1939, 46, 65.

22 Władysław Bartoszewski, 1859 dni Warszawy (Kraków: Wyd. Znak, 1974), 94. 
stanowiły bowiem realizację rozkazu Franka i miały charakter szeroko zakrojonej w GG nadzwyczajnej akcji pacyfikacyjnej, wymierzonej w polską inteligencję, tzw. akcja AB. ${ }^{23}$ Władysław Bartoszewski oceniał po latach: „Żyjąc dziś w demokratycznym kraju, trudno sobie wyobrazić, że niemiecki żołnierz czy żandarm dostawał rozkaz, by przyprowadzić dwudziestu ludzi, inteligentów. Ale jak do licha rozpoznać takich ludzi wśród przechodniów? Niemiec stawał na rogu ulicy, przyglądał się i wołał: Du, Brillenträger! To są fakty, noszenie okularów naprawdę mogło być przyczyną wysłania zupełnie przypadkowego człowieka do obozu koncentracyjnego". ${ }^{24} \mathrm{~W}$ innym miejscu wskazywał: „Na tym właśnie polegało piekło Auschwitz. SS-mani, często tylko stali i patrzyli, działali w białych rękawiczkach. Hierarchia była tak zbudowana, że już Oberscharführer, czyli odpowiednik polskiego młodszego sierżanta był półbogiem, panem życia i śmierci. Ba, nawet zwykły SS-man czy Sturmmann [...] miał wielką władzę, swoją władzą się delektował, ale w gruncie rzeczy nie lubił brudzić sobie rąk. My byliśmy podludźmi, a podludźmi zajmowali się ludzie niższego rzędu, niemieccy kryminaliści lub inni funkcyjni [...]. Zresztą typowi sadyści byli wbrew pozorom w mniejszości, a sadysta ma ochotę bić, znęcać się, widzieć cierpienie, płacz i krew. Powtarzam: SS-mani z reguły kazali to robić innym i rzadko się nawet wtrącali”." 25

Dokumenty wskazują, że wśród funkcjonariuszy niemieckiego aparatu policyjnego znajdowało się mnóstwo osób, których nie można uznać za „prawdziwych sadystów”, a ich pracy na polskich terenach za formę kary. Wręcz przeciwnie, ich służba stanowiła metodyczne działanie antypolskie, a czynności służbowe nierzadko przynosiły realne efekty i uznanie przełożonych, a $\mathrm{z}$ tym awanse i odznaczenia. Jeśli nie można tego uznać za spełnienie marzeń w sferze zawodowej, to jakiego należy użyć określenia? Nie jest moim celem wskazywać Autorowi odpowiedzi wszystkich funkcjonariuszy spełniających tę przesłankę, bowiem byłoby to niemożliwe do wykonania $\mathrm{z}$ uwagi na ograniczony charakter opracowania. Przytoczę jedynie kilka przykładów. Paul Fuchs - funkcjonariusz Komendy Sicherheitspolizei (Komandeur der Sicherheitspolizei - KdS) w Radomiu od 1941 r. Od 1942 r. był on dowódcą referatu IV A, który stał się wkrótce najważniejszym referatem tej jednostki. 1 listopada 1942 r. utworzono w nim komórkę IV N służby wywiadowczej. Komórka o takim charakterze nieznana była placówkom działającym na terenie macierzystym III Rzeszy, a jej powstanie spowodowane było faktem, że podział referatów gestapo przeniesiony z Rzeszy na terenach polskich okazał się nieprzydatny. Fuchs - nazywany „Lisem

\footnotetext{
23 Ibid., 94, 118, 124, 132.

24 Bartoszewski, Mój Auschwitz, rozmowę przeprowadzili Piotr Cywiński i Marek Zając (Kraków: Wyd. Znak, 2010), 12.

25 Ibid., 30.
} 
z Radomia” z powodu uzyskiwanych dobrych osiągnięć $\mathrm{w}$ walce $\mathrm{z}$ polskim podziemiem - $\mathrm{w}$ niedługim czasie stał się postacią dominującą $\mathrm{w}$ radomskim KdS. Według Włodzimierza Borodzieja rola Fuchsa w zwalczaniu podziemia znacznie wykraczała poza zakres zajmowanego stanowiska. W akcjach tych często działał wbrew zaleceniom władz zwierzchnich w Radomiu, jednak z poparciem berlińskiego Głównego Urzędu Bezpieczeństwa Rzeszy (Reichssicherheitshauptamt) i osiągał znaczne rezultaty w zwalczaniu konspiracji polskiej. 1 lipca 1943 r. awansował do stopnia SS-Hauptsturmführera. Został również dwukrotnie odznaczony za osiągane rezultaty. ${ }^{26} \mathrm{Czy}$ Autor odpowiedzi miał na myśli takie rozumienie działania „wbrew rozkazom przełożonych", które skutkowało awansem i odznaczeniami? Chyba nie, bowiem burzy to jego tezę o braku sukcesów w ich karierze. Alfred Spielker w okresie od 1940 r. do lutego 1942 r. był funkcjonariuszem KdS Kraków, zaś w czasie od marca 1943 r. do 1 sierpnia 1944 r. w Sonderkommando IV AS KdS Warszawa i podlegał bezpośrednio Berlinowi. Spilker został podniesiony do stopnia SS-Hauptsturmführera i radcy kryminalnego 9 listopada $1943 \mathrm{r}$. Awanse na wyższe stopnie służbowe otrzymali również: w 1943 r. SS-Hauptsturmführer Wolfgang Birkner z KdS Warszawa, zaś w kwietniu 1944 r. SS-Standartenführer Ludwik Hahn. ${ }^{27} \mathrm{Za}$ działalność przeciwko podziemiu odznaczenia Krzyżem Żelaznym II klasy uzyskali m.in. SS-Sturmscharführer Otto Büssing i SS-Sturmscharführer Wolfgang Rehn z KdS Radom. Ciekawym przykładem jest SS-Obersturmführer Herman Marz, który od 1942 r. był funkcjonariuszem jednostki KdS w Kielcach, a następnie przeniesiono go do Berlina, by później przekazać go do „ważnych działan”" w Warszawie. ${ }^{28}$ Nie ulega wątpliwości, że w życiu codziennym, rodzinnym można było nazwać funkcjonariuszy administracji i policji niemieckiej „przyzwoitymi ludźmi”, lecz to pozostawało bez wpływu na ich działania służbowe. Wydaje się, że dość dobrze opisuje to relacja świadka, która w odniesieniu do SS-Hauptscharführera Gerharda Palitzscha - m.in. przeprowadzającego rozstrzelania więźniów pod Ścianą Śmierci bloku $11 \mathrm{KL}$ Auschwitz - wspominała, że w życiu rodzinnym był on bardzo dobry, kochał żonę i dziecko. Jednak przez więźniów obozu był uznawany za wcielenie zła. ${ }^{29}$ Demonicznym fenomenem jest

26 Włodzimierz Borodziej, Terror i polityka: policja niemiecka a polski ruch oporu w GG 1939-1944 (Warszawa: Instytut Wyd. „Pax”, 1985), 44-46.

27 Regina Domańska, „Policja Bezpieczeństwa dystryktu warszawskiego i jej więzienie «śledcze» Pawiak," Biuletyn Głównej Komisji Badania Zbrodni Hitlerowskich w Polsce 28, (1978): 202, 208. W 1939 r. Hahn miał stopień SS-Sturmbannführera, zob. Wroński, Kronika, 33.

28 Maria Michalczyk, Diabeł „Piątej Kolumny” (Inowrocław: Ludowa Spółdzielnia Wydawnicza, 1985), 177-180.

29 Życie prywatne esesmanów w Auschwitz, wyb. i oprac. Piotr Setkiewicz (Oświęcim: Państwowe Muzeum Auschwitz-Birkenau, 2012), 57. 
właśnie to, że ci „uczciwi ludzie” tak zmienili się pod wpływem wpajanej im ideologii, że w bezwzględny sposób likwidowali przeciwników panującego w III Rzeszy systemu, uznając ich za niższy gatunek ludzi.

Wydaje się, że Autor odpowiedzi, epatując zwrotami o nieustannym zagrożeniu życia funkcjonariuszy niemieckich, otaczającej ich nienawiści społeczeństwa polskiego, niższym standardzie życia niż w Niemczech, braku stabilnej kariery, które skutkowały negatywnym nastawieniem Niemców (s. 207), ubolewa nad losem „biednych” najeźdźców Polski. Zapomina przy tym, że sami sobie zgotowali ten los. Negatywne nastawienie było spowodowane ich własną polityką eksterminacyjną Polaków. Początkowo wybuch wojny i zajęcie kraju były traktowane przez polską ludność podobnie jak zajęcie terenu Polski przez Niemców w I wojnie światowej. To polityka rozbioru kraju na część włączoną do Rzeszy i GG, a także wyniszczenia ludności polskiej (życiowa, żywnościowa, płacowa itp.), wszechwładny terror i masowe egzekucje doprowadziły do wrogiego nastawienia i walki o własny byt oraz wyzwolenie narodu. Autor odpowiedzi nie bierze pod uwagę również większych możliwości zaopatrzenia się w produkty żywnościowe niż na terenie III Rzeszy, ${ }^{30} \mathrm{np}$. dzięki przejmowaniu tzw. szmuglu żywności czy uzyskiwaniu słodyczy z zakładów „Wedla” w Warszawie, które w Rzeszy były reglamentowane, a z których korzystali funkcjonariusze KdS Warszawa. ${ }^{31}$ Nadto mieli oni takie same dodatki, jakie przysługiwały w Rzeszy. W trakcie narady u Franka w dniu 1 grudnia 1939 r. zauważono, że „personel gubernatorstwa składa się z sił urzędniczych starej Rzeszy, które zostały tutaj oddelegowane i pracowników zatrudnionych $\mathrm{w}$ gubernatorstwie [...]. Ludzie ci podlegają systemowi umów zbiorowych Rzeszy. Otrzymują w zasadzie te same dodatki, co delegowane tutaj siły urzędnicze [...]. Przyznawane tutejszym pracownikom dodatki, a mianowicie mieszkaniowy, ubraniowy i diety $\mathrm{z}$ tytułu zatrudnienia itp. są [...] w takiej wysokości, że wyrównują różnice $\mathrm{w}$ wynagrodzeniach. Jest niedopuszczalne, aby zatrudnieni tu pracownicy mieli mniejsze pensje niż te, które mieli w Rzeszy" ${ }^{32}$ Należy również zaznaczyć, że zorganizowany polski opór zbrojny rozpoczął się dopiero w 1943 r., zaś wcześniej - bo pod koniec listopada 1942 r. - jedynie na Zamojszczyźnie, co było związane z wysiedlaniem ludności polskiej w ramach Generalplan

30 Przykładowo w czasie narady 1 XII 1939 r. Frank powiedział, że „należy zapobiegać przesyłaniu żywności [z GG - B. Sz.] pocztą polową, bowiem zakłóci to porządek zaopatrzenia w żywność w ojczyźnie [Rzeszy - B. Sz.]”, zob. AIPN GK 95/1, Omówienie spraw bieżącym z Arturem Seyssem-Inquartem, dr. Josefem Bühlerem, dr. Maxem du Prelem i Johannem von Wühlischem, Kraków, 5 XII 1939 r., 81-86; Frank, Rok 1939, 104.

31 Anna Borkiewicz-Celińska, Batalion „Zośka” (Warszawa: Państwowy Instytut Wydawniczy, 1990), 147.

32 AIPN, GK 95/1, Omówienie spraw bieżącym z Arturem Seyssem-Inquartem, dr. Josefem Bühlerem, dr. Maxem du Prelem i Johannem von Wühlischem, Kraków, 5 XII 1939 r., 81-86; Frank, Rok 1939, 113-114. 
Ost. ${ }^{33}$ Nie należy przy tym zapominać, że zgodnie z rozkazami podziemia walkę bieżącą prowadzono jedynie $\mathrm{z}$ administracją oraz szeroko rozumianymi jednostkami policyjnymi i współpracującymi z nimi obywatelami polskimi. W rzeczywistości działalność sądownictwa konspiracyjnego ograniczała się tylko do obywateli polskich działających na szkodę społeczeństwa lub Sił Zbrojnych w Kraju. Likwidacja niemieckich urzędników aparatu policyjno-administracyjnego nie wymagała uprzedniego wydania wyroku sądu podziemnego, co oparto na fakcie, że między Polską a Niemcami był stan wojny. Ta sytuacja dawała prawo - o ile osoby te, działając $w$ ramach rozkazodawstwa niemieckiego, były czynne w aktach wrogich w stosunku do obywateli państwa polskiego - polskim organizacjom zbrojnym likwidacji takich osób bez wyroku sądu. ${ }^{34} \mathrm{~W}$ rozkazie Komendanta Sił Zbrojnych w Kraju o uregulowaniu akcji bieżącej na obszarach i w okręgach AK z 13 marca 1943 r. pisano, że celem akcji bojowych było: „nękanie przeciwnika i zadawanie mu coraz mocniejszych ciosów przez [...] stosowanie w chwili obecnej wobec okupanta odwetu za akcje gwałtu w stosunku do ludności polskiej [...]. Nie wykonywać aktów terrorystycznych przeciwko wojsku (Wehrmacht) n[ie] p[rzyjacie]la. W szczególności atakować Gestapo, policję, SS, oddziały partyjne, administrację okupacyjną.".

Nadto tezie autora o braku stabilnej kariery przeczą działania np. Fuchsa czy Spilkera. Przykładowo w odniesieniu do Rudolfa Hessa, komendanta KL Auschwitz-Birkenau, wspominano: „Z oświadczeń Hessowej zorientowałem się, że Hessowi bardzo zależało na utrzymaniu się w Oświęcimiu, że przeniesienie do centrali, mimo awansu w Wirtschafts- i Verwaltungshauptamt, nie odpowiadało $\mathrm{mu}$, że przeniesienie uważa za wynik intryg ze strony kierownika gospodarstw rolnych obozu". ${ }^{36}$ Większość Niemców gorliwie wykonujących rozkazy przełożonych miała na terenach polskich otwartą drogę do kariery. Należy podkreślić, że Autor w swojej argumentacji popada również w sprzeczność. $Z$ jednej strony wskazuje, że kariery zrobili tylko sadyści, zaś z drugiej zauważa, że było to wynikiem wyznawanej przez Niemców ideologii Herrenrasse (s. 208-209). Skoro było to wynikiem zaplanowanego działania opartego na ideologicznych podstawach, nie można uznać, że wykonywały to jedynie jednostki ludzkie o sadystycznych upodobaniach.

\footnotetext{
33 Markiewicz, Nie dali, 56.

34 Archiwum Akt Nowych, Archiwum Bernarda i Haliny Zakrzewskich, teczka 41, Bernard Zakrzewski, Organizacja Wydziału Bezpieczeństwa i Kontrwywiadu w II Oddziale Komendy Głównej, b.m., b.d., 57, mps; teczka 42, Bernard Zakrzewski, Kontrwywiad, b.m., b.d., 11, mps.

35 „Rozkaz nr 252/Kdw Komendanta Głównego AK dot. uregulowania akcji bieżącej w obszarach i okręgach, 13 III 1943 r.," w Dokumenty do dziejów Zgrupowań Partyzanckich AK „Ponu$r y$ ”, red. Marek Jedynak (Kielce-Kraków: Wyd. Instytutu Pamięci Narodowej, 2014 ), 72.
}

36 Setkiewicz, Życie prywatne, 127. 
Chyba że w ten sposób Autor odpowiedzi próbuje przekonać czytelnika, że wszystkie osoby popierające ideologię III Rzeszy były sadystami, ale takie stanowisko nie zostało poparte dotychczas żadnymi dowodami.

Nie można zaakceptować również kolejnych tez Autora co do bagatelizowania wiedzy o podziemiu poprzez sprowadzenie go do „terroru niezadowolonych z nowych realiów fundamentalistów" oraz składaniu zafałszowanych meldunków w obawie przed wykazaniem się niekompetencją i związanymi z tym sankcjami dyscyplinarnymi. Jako kuriozalne wręcz jawi się uargumentowanie tej tezy troską o spokojny przebieg służby (s. 208-209). Tym bardziej że jak zauważył Autor odpowiedzi: „jego teza nie znajduje potwierdzenia w źródłach" (s. 209). Autor przedstawił w tym miejscu ciekawą interpretację wskazującą, iż jeśli potwierdzenia jego tezy nie ma w materiale źródłowym, pomimo tego trzeba uznać ją za prawidłową i dopuszczalną. Powyższe wnioskowanie kłóci się nie tylko z warsztatem historyka, gdzie występuje krytyka źródeł, lecz również z zasadami logicznego rozumowania prawniczego, w którym przypuszczenia i tezy opiera się na przeprowadzonych dowodach, nie zaś na braku ich wystąpienia. Należy zauważyć, że argumentacji Autora przeczy analiza zachowania Niemców, którym zależało na zdławieniu wszelkiego oporu. Teren Polski był bowiem przewidziany do zagospodarowania, obsadzenia niemieckimi osadnikami, przy których Polacy mieli wykonywać czynności jako niezbyt wykształcona siła robocza. To wymagało zlikwidowania oporu mieszkańców, a więc wbrew tezie Autora - nie chodziło o bezproblemową służbę, lecz dokładne rozpoznanie wrogich sił i ich likwidację. Na marginesie należy wskazać, że Niemcy odnosili na tym polu znaczne sukcesy. Po drugie, pogląd Autora odpowiedzi negują zachowane meldunki. Przykładowo w raporcie gubernatora dystryktu warszawskiego Ludwiga Fischera z 15 kwietnia 1940 r. zapisano: „Opór polskiej ludności wiejskiej przeciw wysyłce do Rzeszy nasilił się. Powszechna niechęć do słuchania wezwań władz niemieckich staje się coraz bardziej problemem politycznym. Były rząd polski nadal potajemnie prowadzi podburzającą propagandę przeciw Rzeszy. W Warszawie stwierdzono istnienie tajnej gazety rozpowszechniającej informacje o przerażających warunkach pracy na roli w Niemczech. Wpływu tej propagandy nie można szybko zniwelować" ${ }^{37} \mathrm{~W}$ kolejnym raporcie z 11 października 1943 r. stwierdzano: „O nasileniu się zamachów świadczy wyraźnie liczba zabitych i rannych. W sierpniu po stronie niemieckiej padło 9 osób cywilnych i 23 członków Wehrmachtu, SS i policji, a wśród Polaków zamordowano 44 osoby cywilne i 9 polskich policjantów. We wrześniu liczba poległych Niemców wzrosła do 16 cywilnych Reichsdeutschów oraz

37 Raporty Ludwiga Fischera Gubernatora Dystryktu Warszawskiego 1939-1944, wyb. i oprac. Krzysztof Dunin-Wąsowicz et al. (Warszawa: Książka i Wiedza, 1987), 168. 
37 członków Wehrmachtu, SS i policji, gdy wśród Polaków zamordowano 35 osób cywilnych i 9 polskich policjantów. Dodać trzeba niemałą liczbę rannych [...]. Przy istniejących siłach policyjnych nie da się z pewnością dokonać w tej dziedzinie zasadniczej zmiany" ${ }^{38} \mathrm{~W}$ kolejnym meldunku dotyczącym rozbicia w dniu 7 grudnia 1942 r. IV Odcinka „Wachlarza” informowano: „Wykryta organizacja jest polską grupą terrorystyczną o nazwie «Kierunek», rozlokowaną na całym terytorium Białorusi i Ukrainy. Swoją siedzibę ma w Warszawie, ale kieruje nią i finansuje Londyn. Prawdopodobnie chodzi o czysto militarną formację. W Warszawie ma znajdować się w tamtejszym oddziale głównym wielu polskich skoczków spadochronowych, którzy dowodzą całą organizacją [...]. Organizacja przygotowuje wysadzanie ważnych punktów kolejowych i komunikacyjnych na wypadek odwrotu wojsk niemieckich. Jednak właśnie już teraz otrzymała ona już zadanie dywersji na najważniejszych liniach kolejowych, celem uniemożliwienia dostaw na front". ${ }^{39}$

W raporcie szefa radomskiego KdS do Alfreda Spilkera na temat grupy „Muszkieterzy”, dowodzonej przez inż. Stefana Witkowskiego, informowano: "Już wcześniej donosiłem o zachodniej grupie ZWZ, która w Niemczech rozbudowała dobrze funkcjonujący aparat wywiadowczy i która dysponuje stosunkami w niemieckim przemyśle wojennym. Małe i niewinne są te stosunki w porównaniu do stosunków "Muszkieterów", którzy za ciężkie pieniądze mają swoich ludzi w nadzwyczaj ważnych zakładach [...]. Zasięg ich wpływów mogłaby najbardziej trafnie naświetlić sprawa materiału wywiadowczego, który oni otrzymują z Kwatery Głównej Führera". ${ }^{40}$

Przeczy temu również raport gen. Reinharda Gehlena, stanowiący zestawienie danych posiadanych przez Niemców o Polskim Państwie Podziemnym. Wskazano tam, oprócz przytoczonych szkiców (w tym struktury AK w okręgu radomskim, tras przelotowych samolotów $\mathrm{z}$ „cichociemnymi” w okresie grudzień 1941 - grudzień 1944 r. i zestawień np. „Istoty działań polskich służb wywiadu” czy „Planu ogólnego zbierania informacji AK”) m.in., że „Polski wywiad wniósł znaczący wkład w rozwój ogólnoeuropejskiego ruchu oporu przeciw niemieckiej budowie Nowej Europy”. ${ }^{41}$ Już

\footnotetext{
38 Ibid., 691.

39 Cezary Chlebowski, Wachlarz: Monografia Wydzielonej Organizacji Dywersyjnej Armii Krajowej wrzesień 1941 - marzec 1943 (Warszawa: Instytut Wydawniczy „Pax”, 1990), 217-218.

40 Piotr Matusak, Wywiad Związu Walki Zbrojnej Armii Krajowej 1939-1945 (Warszawa: Ludowa Spółdzielnia Wydawnicza, 2002), 37.

${ }^{41}$ Reinhard Gehlen, Polskie podziemie w oczach wroga. Tajny raport dowódcy niemieckiego wywiadu gen. Reinharda Gehlena, oprac. nauk. Jan Rydel i Andrzej L. Sowa, tłum. Mariusz Stinia i Jan Rydel (Kraków: Wyd. M, 2016), 55.
} 
powyższe, niewielkie $\mathrm{w}$ istocie, przytoczenie meldunków niemieckich przeczy przyjętej przez Autora tezie.

Można przy tym zauważyć, że Autor odpowiedzi popadł w pewną sprzeczność logiczną. Z jednej strony bowiem twierdzi, że brak stabilnej kariery na terenie GG skutkował negatywnym nastawieniem Niemców do tego terenu, co wskazywałoby na chęć jego jak najszybszego opuszczenia, z drugiej zaś na fałszowanie meldunków o działaniach podziemia, które miały skutkować spokojnym przebiegiem ich służby. W takim wypadku chyba lepsze było dyscyplinarne przeniesienie do innej służby, np. w Rzeszy, niż pozostawanie na wrogim, nienawistnym terytorium?

Należy zadać sobie pytanie, co spowodowało, że Autor odpowiedzi pokusił się o przedstawienie powyższego opracowania? Przyznam, iż po jego lekturze nie jestem w stanie udzielić na to odpowiedzi. Oprócz początkowego akapitu, w którym Autor podziękował za pozytywne zrecenzowanie jego publikacji oraz wyjaśnienia, że jego książka była dedykowana niemieckiemu czytelnikowi, w zasadzie każdy następny akapit odpowiedzi zdaje się wskazywać, że argumentacja Autora w temacie realiów zajętych przez Niemców terenów Polski oraz ich podejścia do Polaków odbiega od materiałów utrwalonych w źródłach historycznych i aktach prawnych. To musi tym bardziej dziwić, że w swojej publikacji nie usprawiedliwiał III Rzeszy.

Bartłomiej Szyprowski (Warszawa) 